REVIEW ARTICLE

\title{
鉄を視点とするアスベスト発がんの解明と 予防・診断・治療への応用の可能性
}

\author{
豊國伸哉1
}

\section{Elucidation of Asbestos-induced Carcinogenesis and Its Application to Prevention, Diagnosis and Treatment in Relation to Iron}

\author{
Shinya Toyokuni 1 \\ ${ }^{1}$ Department of Pathology and Biological Responses, Graduate School of Medicine, Nagoya University, Japan.
}

ABSTRACT - Objective. Respiratory exposure to asbestos has been associated with mesothelioma in humans. However, its carcinogenic mechanism is still unclear. Methods. Here we studied the ability of chrysotile, crocidolite and amosite fibers to induce oxidative DNA damage and the modifying factors using 4 distinct approaches. Results. Electron spin resonance analyses showed that crocidolite and amosite containing high amounts of iron, but not chrysotile, catalyzed hydroxyl radical formation in the presence of hydrogen peroxide, which was enhanced by an iron chelator, nitrilotriacetic acid, and suppressed by Desferal ${ }^{\circledR}$. Iron chelators, such as citrate, ATP and GTP, did not inhibit this reaction. Second, we used time-lapse videomicroscopy to evaluate how cells deal with asbestos fibers. RAW264.7 cells, MeT-5A and HeLa cells engulfed asbestos fibers, which reached not only cytoplasm but also the nucleus. Third, we utilized supercoiled plasmid DNA to evaluate the ability of each type of asbestos to induce DNA double strand breaks (DSBs). Crocidolite and amosite, but not chrysotile, induced DNA DSBs in the presence of iron chelators. We cloned the fragments to identify break ends. DSBs tended to occur within repeat sequences and between two G:C sequences. Finally, intraperitoneal administration of each type of asbestos to rats induced not only formation of nuclear 8-hydroxy-2'-deoxyguanosine in the mesothelium but also significant iron deposits in the spleen. Conclusion. Together with the established carcinogenicity of intraperitoneal chrysotile, our data suggest that asbestos-associated catalytic iron, whether constitutional or induced by other mechanisms, plays a role in asbestos-induced carcinogenesis and that chemoprevention may be possible through targeting the catalytic iron.

KEY WORDS — Asbestos, Mesothelioma, Iron, Oxidative stress

(JJLC. 2009;49:362-367)

Reprints: Shinya Toyokuni, Department of Pathology and Biological Responses, Graduate School of Medicine, Nagoya University, 65 Tsurumai-cho, Showa-ku, Nagoya 466-8550, Japan (e-mail: toyokuni@med.nagoya-u.ac.jp).

要旨一一目的. アスベストの発がん機構を解明する.

方法.アスベスト (UICC : クリソタイル，クロシドライ

ト, アモサイト)の物理化学的な性質を再検討する一方, 培養細胞や実験動物個体にアスベストの投与を行い, 生 物学的性質を詳細に評価した。結果. ラジカル発生の触 媒能はアモサイト>クロシドライト>>>クリソタイル であり,それは種々のキレート剤の存在で修飾を受けた. 食食細胞以外に，中皮細胞や腺癌細胞もアスベスト繊維
を取り込み，核内にいたることを観察した. supercoiled plasmid DNA を使用して, 各アスベストの 2 本鎖 DNA 切断能を検討した. 鉄含量の高いアモサイトとクロシド ライトで 2 本鎖切断を認め, 繰り返し配列部位や $\mathrm{G}: \mathrm{C}$ 塩基間で切断しやすいことが判明した. ラット腹腔内に 各アスベスト繊維を投与すると, 全アスベスト投与グ ループで, 中皮細胞で酸化ストレス増加を認めるととも に特に脾臓において鉄沈着を認めた。結論. クリソタイ
1名古屋大学大学院医学系研究科病理病態学講座生体反応病理 学/分子病理診断学.

別刷請求先：豊國伸哉, 名古屋大学大学院医学系研究科病理病

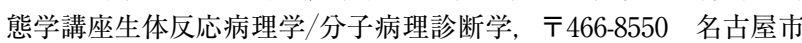

昭和区鶴舞町 65 (e-mail: toyokuni@med.nagoya-u.ac.jp).

※第 48 回日本肺癌学会総会シンポジゥム「悪性中皮腫の克服に 向けて」. 
ル腹腔内投与も中皮腫を発生する事実と考えあわせる と，アスベスト発がんにはアスベストに含まれる鉄のみ ならず，他の機序で発生する過剰鉄も重要な役割を演じ
ていることが示唆され, 中皮腫発生の予防標的として期 待される.

索引用語——アスベスト, 中皮腫, 鉄, 酸化ストレス

\section{はじめに}

石綿（アスベスト）曝露と悪性腫瘍，特に中皮腫や肺 癌との関連性は 50 年以上前より着目され, 多くの疫学的 調查がこれを支持しているが，その発がん機構に関して は未だ不明な点が多い. 欧米では 1990 年代にアスベスト 繊維使用の法的規制が取られるようになり，それ以後研 究は下火となっていた. しかしながら, 日本のアスベス 卜輸入量から予測される中皮腫発生のピークは 2020 年 であり, 今後合計 10 万人以上の発生が予想される. 1 こ のような状況においては，既にアスベスト曝露を受けた 人においてどのような予防手段を取っていくかが極めて 重要となる。そのためには，アスベスト繊維が中皮腫や 他の悪性腫瘍を発生させるメカニズムを明らかにする必 要がある.

中皮腫発生に関わるメカニズムに関しては，以下の 4 つのカテゴリーに分類できると考えられる. ${ }^{2,3} 1$. 酸化ス トレス説：アスベスト繊維自体に含まれる鉄あるいはア スベスト繊維の異物としての性質より，アスベスト繊維 周辺でフリーラジカル発生に伴う酸化ストレスが生じ, ゲノム DNA や脂質・蛋白質などを傷害する。この過程 が発がんに重要とするもの. ${ }^{4} 2$. 染色体分配障害説 : 細 いアスベスト繊維が細胞分裂の際に染色体に絡まり，ゲ ノムに染色体レベルの異常を来すとするもの. 3. 特定分 子・変異原性分子の吸着説：アスベスト繊維は吸着力が 高いため, 生体内の特定の分子を吸着したり, 体外から の変異原性分子を吸着し, これが発がんに寄与すると考 えるもの. 4. ウイルス説 : 1960 年代にヨーロッパでポ リオのワクチンにSV40 ウイルスの污染があったという 事実があり, この不死化能を持つウイルス感染が発がん の原因と考えるもの. しかし，本説はこれまでの研究に より日本においては否定的であるとされる．今回の実験 においては, アスベストの物理化学的な性質を再検討す る一方，培養細胞や実験動物個体にアスベストの投与を 行い生物学的性質を詳細に評価した.

\section{方 法}

\section{アスベスト繊維の形態・成分元素の解析}

アスベスト繊維(UICC ; クリソタイル A, クロシドラ イト, アモサイト）を労働安全衛生総合研究所より入手 し, 走査型電子顕微鏡（Hitachi S-4700）により形態の観
察を行った。同時にX 線分析 (EDS, Horiba SuperXenography, EMAX-5770）を行い，成分元素を解析した. アスベスト繊維のフリーラジカル産生触媒能の解析

アスベスト繊維と過酸化水素を混合し， スピンとラッ プ剂（DMPO：5,5-dimethyl-1-pyrroline N-oxide）の存在 下でラジカルが発生するかどうかを electron spin resonance (ESR) で解析した。この際, 種々の人工あるいは 細胞内に存在する天然の鉄キレート剤の及ぼす影響を検 討した. 5

\section{アスベスト繊維の変異原性と変異スペクトラムの検討}

過酸化水素存在下に 2 本鎖 supercoiled plasmid DNA を使用して, DNA 鎖切断とその切断部位の特性をアガ ロースゲル電気泳動と DNA 断片のクローニング・切断 端塩基配列決定により検討した. ${ }^{6,7}$

\section{培養細胞のアスベスト繊維処理の観察}

タイムラプス顕微鏡（Olympus IX70 ; iXon DV887, Andor Technology ; Metamorph software, Molecular Devices）を使用して, 種々の培養細胞がアスベスト繊維 の添加にどう対処するのかを観察した.

\section{動物モデルの評価}

8 週令雄ウィスターラット（各群 3 匹）に各アスベスト 緎維 $10 \mathrm{mg}$ を投与し, 1 週間後, 4 週間後に屠殺し, 主要 臓器を病理学的に検討した。ヘマトキシリン・エオジン 染色ならびに鉄染色（Perl's iron staining）を施行した. また, 8-hydroxy-2'-deoxyguanosine の免疫染色を avidin biotin complex 法で行った. 8,9

\section{結 果}

\section{アスベスト繊維のフリーラジカル生成能の解析}

標準化された 3 種類のアスベスト繊維（クリソタイル A, クロシドライト, アモサイト)の形状を走査型電子顕 微鏡で観察し，その含有元素を測定した. クロシドライ トとアモサイトに鉄が多量に含まれていることが確認さ れた (Figure 1A，1B). ESR を使用して, 各アスベスト 繊維のフリーラジカル産生能を測定した. 過酸化水素 $(10$ mM）の存在下でアスベスト繊維を触媒としてヒドロキ シラジカルが発生し， 3 種類のアスベスト繊維のうちア モサイトのフリーラジカル生成能が最も高いことが判明 した(Figure 1C).この反応を調節する可能性のある合成 鉄キレート率 4 種 $\left(\right.$ Desferal ${ }^{\mathbb{R}}$, DES ; diethylenetriaminepenta-acetic acid, DTPA ; ethylenediaminetetra-acetic 


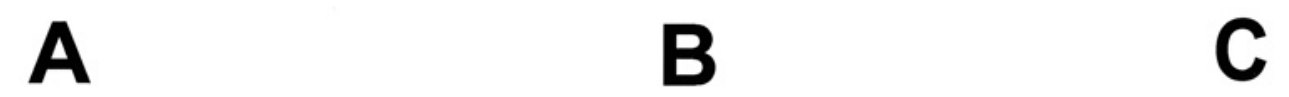

\section{Iron content}
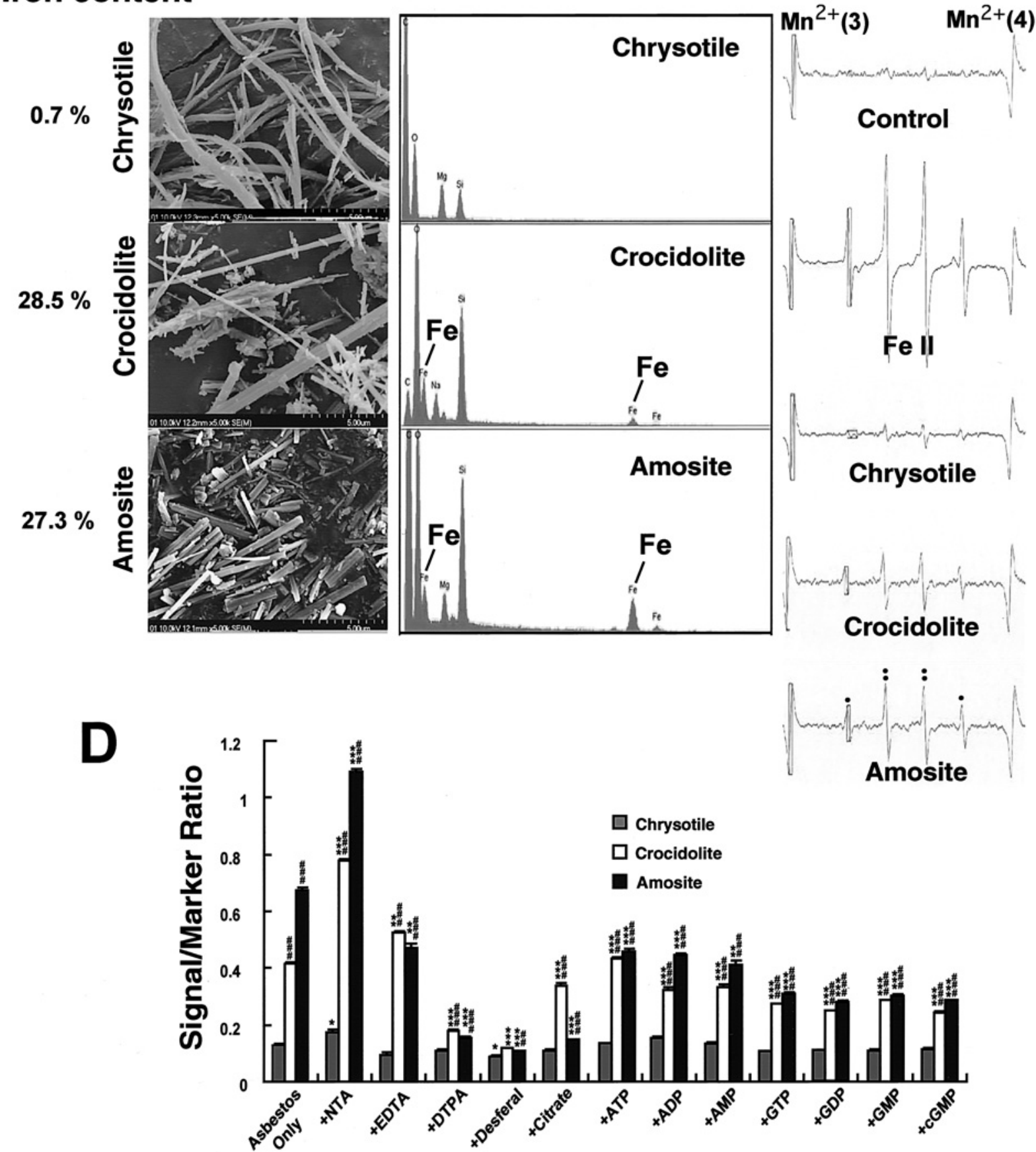

Figure 1. Morphological and compositional analyses of asbestos fibers and their catalytic activity for free radical generation. A; Morphological analysis by scanning electronmicroscopy. B; Compositional analysis by X-ray. C; ESR analysis in the presence of hydrogen peroxide. D; Modification of catalytic activity of asbestos fibers by different iron chelators (*vs asbestos only, \# vs chrysotile; *, \#, $\mathrm{P}<0.05 ; * *, \# \#, \mathrm{P}<0.01 ; * * *, \# \# \#, \mathrm{P}<0.001$ ).

acid, EDTA ; nitrilotriacetic acid，NTA）あるいは細胞 内に常在するキレート分子 8 種 (citrate, ATP, ADP, $\mathrm{AMP}, \mathrm{GTP}, \mathrm{GDP}, \mathrm{GMP}, \mathrm{cGMP})$ を反応に加え変化を
検討したところ，NTAはこの触媒作用を最も促進する こと, ならびにクエン酸やリン酸化合物の存在下でもア スベスト繊維にはこの触媒作用があることを観察した 


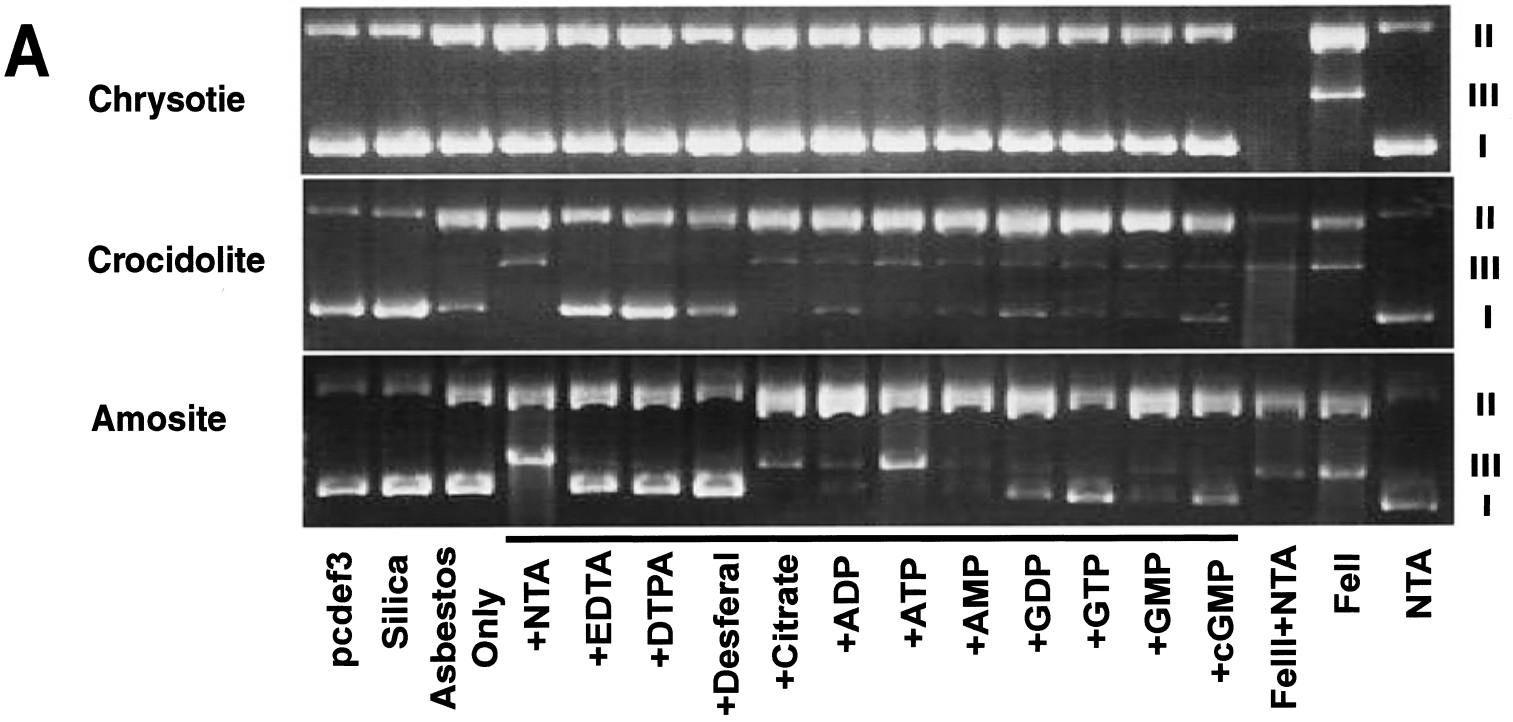

\section{Crocidolite}

\begin{tabular}{|c|c|c|}
\hline $\begin{array}{l}\mathbf{C} \\
\mathbf{T} \\
\mathbf{C} \\
\mathbf{C} \\
\mathbf{G} \\
\mathbf{C} \\
\mathbf{G} \\
\mathbf{G} \\
\mathbf{T} \\
\mathbf{C} \\
\mathbf{G} \\
\mathbf{A} \\
\mathbf{A} \\
\mathbf{C} \\
\mathbf{G} \\
\mathbf{G} \\
\mathbf{G} \\
\mathbf{G} \\
\mathbf{G} \\
\mathbf{G} \\
\mathbf{G} \\
\mathbf{G} \\
\mathbf{C} \\
\mathbf{C} \\
\mathbf{C} \\
\mathbf{C}\end{array}$ & \begin{tabular}{|l} 
AAAATTTAAG \\
GGGCGCTGGG \\
TGGTGGCACC \\
TTTTTCTGG \\
GGGCGGCGAC \\
GTGCGTCCCA \\
CTCTGGTGCC \\
GGCCCTGCTG \\
CGGGTGAGTC \\
AGGGGTTTTA \\
GAGTTTGGAT \\
ITCCATTTCA \\
TGGGGCAGGA \\
GACAATAGCA \\
CCAAACTGGA \\
CTATCTCGGT \\
GGGATTTCGG \\
TTTAACGCGA \\
CGAATTAATT \\
CCCCAGCAGG \\
TAGTGAGGAG \\
GCACGCAGGT \\
CGGCTATCGT \\
GGCGATGCCT \\
TTTTCTGGAT \\
CTATCGCCTT \\
TGGGGTTCGA \\
GGGACGCCGG \\
TGCGGCGAGC \\
CTTACCGGAT \\
TTTGTTTGCA \\
TGCGGCGACC \\
GGGTGAGCAA \\
GGGCGACACG
\end{tabular} & $\begin{array}{l}126 \\
776 \\
803 \\
883 \\
955 \\
962 \\
1052 \\
1153 \\
1205 \\
1346 \\
1457 \\
1502 \\
1843 \\
1865 \\
2260 \\
2293 \\
2331 \\
2376 \\
2383 \\
2509 \\
2694 \\
2819 \\
2994 \\
3363 \\
3405 \\
3566 \\
3603 \\
3905 \\
4203 \\
4481 \\
4583 \\
5682 \\
5885 \\
5931 \\
\end{array}$ \\
\hline
\end{tabular}

\section{Amosite}

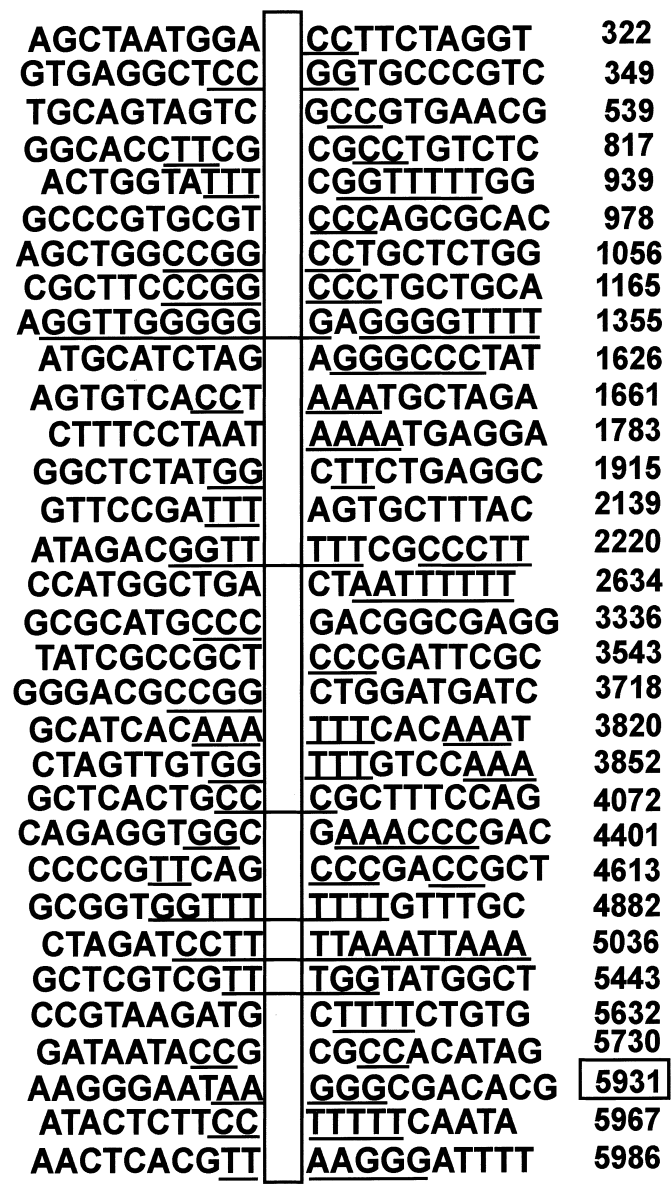

Figure 2. Analyses of in vitro oxidative DNA damage catalyzed by asbestos fibers. Supercoiled plasmid DNA was used to evaluate single and double DNA-strand breaks. A; Single and double strand breaks catalyzed by asbestos fibers in the presence of iron chelators. I, supercoiled form; II, circular form; III, linear form. B; Sequence specificity of crocidolite- or amosite-catalyzed breakpoints in plasmid DNA. 


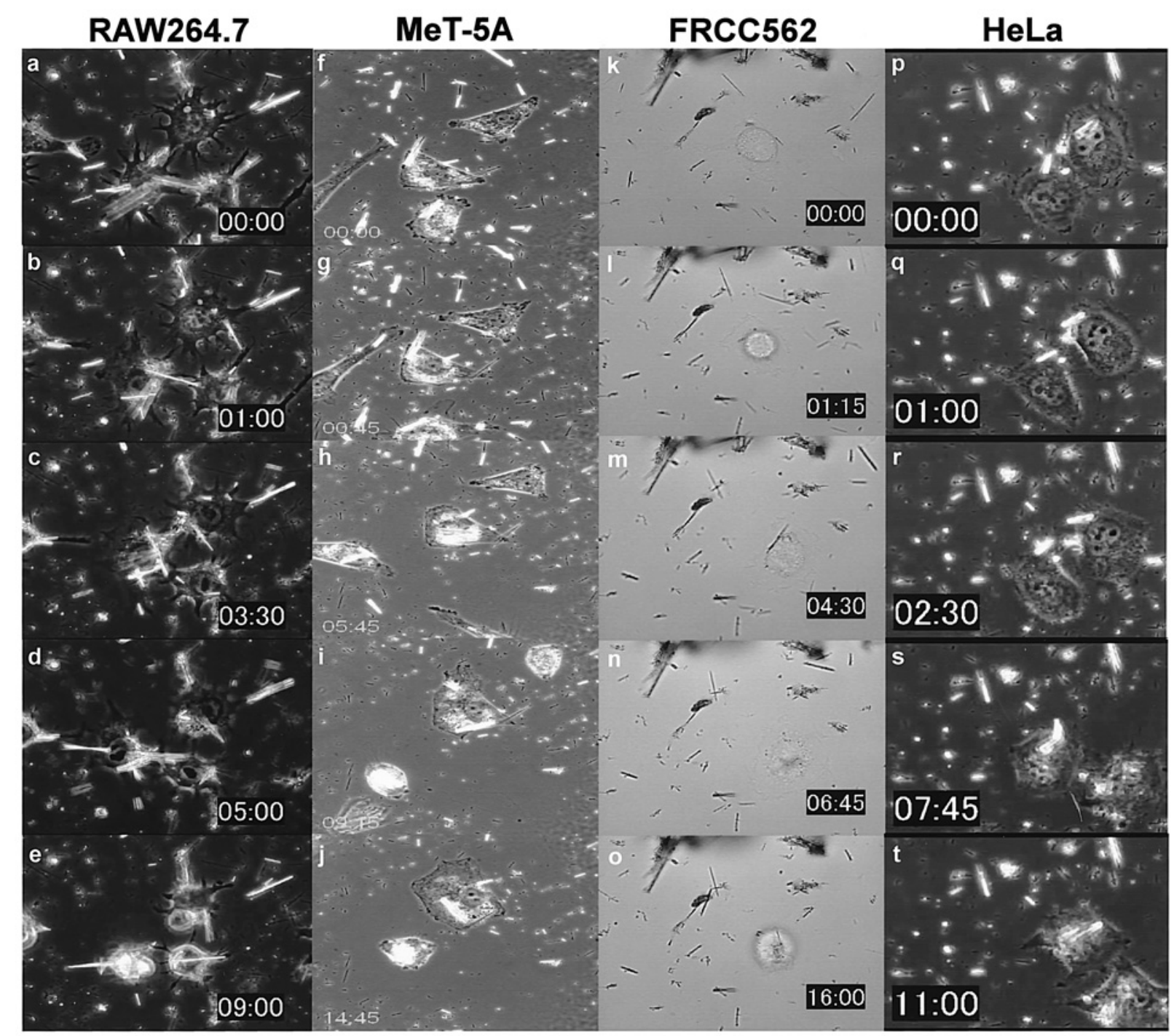

Figure 3. Pictures of time-lapse videomicroscopy. Four different kinds of cells engulfed asbestos fibers (crocidolite).

(Figure 1D).

\section{アスベスト繊維による突然変異特性の解析}

Supercoiled plasmid DNA に過酸化水素存在下にアス ベスト繊維を加え反応させ， 2 本鎖切断の特徽を解析し た. クロシドライトとアモサイトでしかも NTA, ATP, $\mathrm{ADP}$ といったキレート剂の存在下で 2 本鎖切断は起 こった。その切断端はグアニン・シトシン $(\mathrm{G}: \mathrm{C})$ 間で 切れる可能性が高く, また多くの場合切断端両側に繰り 返し配列を認めた（Figure 2A，2B）.

\section{培養細胞のアスベスト繊維処理の観察}

RAW264.7 (マクロファージ), MeT-5A（非トランス フォーム中皮細胞株), FRCC562(鉄ニトリロ三酢酸誘発 ラット腎癌細胞), HeLa (子宮頝部腺癌)のすべての細胞 は 16 時間の継続的観察の間にクロシドライトを細胞内 に取り込み, その一部は核内に到達していた(Figure 3).

\section{アスベスト曝露後の酸化ストレスに関する解析}

アスベスト繊維投与動物の臓器を形態学的に検討する と，アスベスト投与全グループにおいて，中皮細胞で酸 化的 DNA 塩基損傷である 8-hydroxy-2'-deoxyguanosine の染色性が増加すると同時に，脾蔵において著明な鉄の 沈着を認めた（データ省略）.

\section{考 察}

アスベスト繊維そのものの鉄の含量はアモサイト $(\mathrm{Fe}++)>$ クロジライト $(\mathrm{Fe}+++)>>>$ リソタ イルであり, ヒドロキシラジカル発生に関する触媒活性 はこれにほほ比例した．試験管内の変異原性もこれに正 比例をするものであった。ここで, 繰り返し配列や $\mathrm{G}: \mathrm{C}$ を標的としてDNA 2 本鎖切断を起こすことは発がん機 構を考える上でたいへん興味深い。また，これらの反応 
はすべて, 生体に存在する天然の鉄キレート剤の存在下 でも起こることが確認されたことは興味深い.

アスベスト繊維は領食細胞以外の細胞へも積極的に取 り込まれた。 そして, 多くの場合核内に到達することが 明らかとなった。これはアスベスト繊維が細胞内の蛋白 などの分子と親和性が高いことを意味しており，今後そ の同定が重要な課題となるだろう。また，アスベスト繊 維が取り込まれる際，どのような分子あるいは受容体を 介して細胞内へ入るのか, その機序の解明が望まれる.

疫学的な事実に基づいてクロシドライトやアモサイト はヒトで発がん性の高いアスベストとされているが, 10 クリソタイルをラット腹腔内に投与すると，高率に中皮 腫が発生することが知られている.11 今回の結果より, アスベストに既に曝露されたヒトの中皮腫発生予防に は，鉄代謝を鉄欠乏方向へ修飾変化させることが有効で あることが示唆される. この方法にはフリーラジカル反 応の開始を止める作用がある。これまでアスベスト曝露 者に対する肺癌予防に抗酸化剂として $\beta$ カロチンやレ チノールが使用されたが，かえって契煙者の場合肺癌の リスクをあげるというデータが発表されている.12これ は, 抗酸化剂自体が寿命の比較的長いラジカルとなり, ゲノム傷害を促進したためとも解釈される．何らかのキ レート剂で鉄代謝自身を修飾する場合には，契煙者・非 喫煙者に関わらずラジカル反応の収束方向へ作用するこ とが期待される.

\section{REFERENCES}

1. Robinson BW, Lake RA. Advances in malignant mesothelioma. N Engl J Med. 2005;353:1591-1603.

2. Roggli VL, Coin P. Mineralogy of Asbestos. CH 1. In: Roggli VL, Oury TD, Sporn TA, eds. Pathology of asbestos- associated diseases. 2nd ed. New York: Springer Verlag; 2004:1-16.

3. Dodson RF, Hammar SP. Asbestos: Risk assessment, epidemiology, and health effects. Boca Raton: CRC Press, Taylor \& Francis Group; 2006.

4. Kamp DW, Graceffa P, Pryor WA, Weitzman SA. The role of free radicals in asbestos-induced diseases. Free Radic Biol Med. 1992;12:293-315.

5. Kawabata T, Awai M, Kohno M. Generation of active oxygen species by iron nitrilotriacetate (Fe-NTA). Acta Med Okayama. 1986;40:163-173.

6. Toyokuni S, Sagripanti JL. DNA single- and doublestrand breaks produced by ferric nitrilotriacetate in relation to renal tubular carcinogenesis. Carcinogenesis. 1993;14:223-227.

7. Toyokuni S, Sagripanti JL. Induction of oxidative singleand double-strand breaks in DNA by ferric citrate. Free Radic Biol Med. 1993;15:117-123.

8. Toyokuni S, Tanaka T, Hattori Y, Nishiyama Y, Yoshida A, Uchida K, et al. Quantitative immunohistochemical determination of 8-hydroxy-2'-deoxyguanosine by a monoclonal antibody N45.1: its application to ferric nitrilotriacetate-induced renal carcinogenesis model. Lab Invest. 1997;76:365-374.

9. Toyokuni S. Reactive oxygen species-induced molecular damage and its application in pathology. Pathol Int. 1999; 49:91-102.

10. McDonald AD, McDonald JC, Pooley FD. Mineral fibre content of lung in mesothelial tumours in North America. Ann Occup Hyg. 1982;26:417-422.

11. Davis JM, Addison J, Bolton RE, Donaldson K, Jones AD. Inhalation and injection studies in rats using dust samples from chrysotile asbestos prepared by a wet dispersion process. Br J Exp Pathol. 1986;67:113-129.

12. Cullen MR, Barnett MJ, Balmes JR, Cartmel B, Redlich CA, Brodkin CA, et al. Predictors of lung cancer among asbestos-exposed men in the $\beta$-carotene and retinol efficacy trial. Am J Epidemiol. 2005;161:260-270. 